Session 2348

\title{
Trends and Developments in Engineering Technology: Who Are We and Where Are We Going?
}

\author{
Patricia L. Fox, Stephen P. Hundley \\ Indiana University Purdue University Indianapolis (IUPUI)
}

\begin{abstract}
In 1977, a longitudinal survey was developed by a group of engineering technology colleagues to look at trends and developments of baccalaureate engineering technology programs in the United States. Engineering Technology Division (ETD) representatives of the four American Society for Engineering Education (ASEE) zones conducted the surveys in 1977, 1981, 1985, 1990, and 1995. Results of these surveys were reported by region and published in the 1978, 1982, 1986, 1991, and 1996 College Industry Education Conference (CIEC) proceedings. The CIEC conference name was changed to the Conference for Industry and Education Collaboration (CIEC) in 1997.
\end{abstract}

In 1998, members of Engineering Technology Division and the Two-Year College Division (TCD) of ASEE came together to sponsor the 1999 Development and Trends survey, which was conducted nationally. All two- and four-year engineering technology schools were invited to participate in the web-based survey that was conducted in the fall of 1999. Various invitations to participate in the study were sent out via the ETD and TCD listserves.

Separate questionnaires for two- and four-year schools, each of which contained approximately 130 items, were designed by a group of ETD and TCD members. A majority of the questions in the four-year program survey remained unchanged from the original questionnaire that was designed in 1977. Survey questions are divided into four major categories: administrative structure; faculty characteristics; student characteristics; and enrollment, recruiting, retention, placement, and follow-up. The surveys were designed to take approximately twenty to thirty minutes to complete by an administrator of the school/institution.

A total of 129 institutions participated in the 1999 Engineering Technology Trends and Developments Survey. Of these institutions, 62 were four-year schools and 67 were two-year schools. This represents a participation level of approximately $31 \%$ of the total number of engineering technology schools/institutions in the United States. This paper will focus on the national results of engineering technology two- and four-year school surveys for 1999. 


\section{Administrative Structure}

In the first part of the Engineering Technology Trends and Development Survey, administrators were asked to respond to approximately fifty items concerning administrative features and programs in general. Answers to some of the questions about administrative structure, administrative titles of program heads, names of degree awarded, number of credit hours required for a degree, number of courses with technical laboratories, sharing of faculty and space with other programs, and effectiveness of industrial advisory committees are provided in the following paragraphs. Tables of the results from questions in the survey are also provided throughout the paper.

Of all the four-year schools that responded to the survey, $79 \%$ are classified as four-year Universities with very a small number responding as Community \& Technical Colleges, Technical Institutes, Institutes of Technology, or Colleges as shown in Table 1. Table 2 illustrates the responses of two-year schools to a similar classification question, which resulted in $67 \%$ classified as two-year Community Colleges, $18 \%$ as Technical Institutes, and 13\% as Community \& Technical Colleges.

Table 1. Type of Institutions - Four-year schools

\begin{tabular}{|l|c|c|}
\hline Four-year schools & 1999 & 1999 \\
\hline Type of Institution & $\mathrm{N}$ & $\%$ \\
\hline Community \& Technical College & 3 & $5 \%$ \\
\hline Technical Institute & 2 & $3 \%$ \\
\hline Institute of Technology & 2 & $3 \%$ \\
\hline College & 6 & $10 \%$ \\
\hline University & 49 & $79 \%$ \\
\hline Total & 62 & $100 \%$ \\
\hline
\end{tabular}

Table 2. Type of Institutions - Two-year schools

\begin{tabular}{|l|c|c|}
\hline Two-year schools & 1999 & 1999 \\
\hline Type of Institution & $\mathrm{N}$ & $\%$ \\
\hline Community College & 45 & $67 \%$ \\
\hline Community \& Technical College & 9 & $13 \%$ \\
\hline Technical Institute & 12 & $18 \%$ \\
\hline Institute of Technology & 0 & $0 \%$ \\
\hline College & 0 & $0 \%$ \\
\hline University & 1 & $2 \%$ \\
\hline Total & 67 & $100 \%$ \\
\hline
\end{tabular}

Fifty-three percent of four-year schools indicated that the person directly in charge of the engineering technology program(s) holds the title of Chair, followed by $15 \%$ Director, $13 \%$ Head, $11 \%$ Dean, 5\% Coordinator, and 3\% classified with some other title. In $38 \%$ of the twoyear schools, the person in charge is classified as Chair, in $27 \%$ Dean, in $15 \%$ Coordinator, in $6 \%$ Head, in $2 \%$ Director, and in $12 \%$ this person holds some other title. In summary, the typical four-year engineering technology program is housed in a university and directed by a department 
chair. The average two-year program is most often housed in a community college and led by a chair or a dean.

Bachelor of Science programs in $75 \%$ of four-year schools are divided into departments as opposed to being partitioned into schools, colleges, divisions or units. Of the four-year schools reporting, $100 \%$ indicated that the Bachelor of Science is the title of the degree awarded to graduates. Associate Degree programs in two-year schools are structured 51\% as departments and $34 \%$ as divisions with a smaller number classified as schools, colleges, or units. In two-year schools, "Engineering \& Technology" and "Engineering Technology" are widely used to distinguish departments or divisions. Ninety percent of the two-year schools award an Associate of Applied Science Degree.

A majority (55\%) of the four-year programs surveyed require between 129 and 136 semester credit hours for the Bachelor's Degree, while 37\% require between 120 and 128 hours. Of the two-year programs, $15 \%$ require $61-64$ hours, 35\% require $65-68$ hours, $33 \%$ require $69-72$, and $17 \%$ require 73-76 semester credit hours for an Associate Degree.

It appears from the data collected that two-year schools have a higher concentration of technical courses with a required laboratory than four-year schools. More than half of the two-year schools reported that more than $80 \%$ of their courses have a required lab, while only $18 \%$ of four-year schools reported that more than $80 \%$ their courses have a required lab.

In response to a question about sharing faculty with other areas, $51 \%$ of the two-year schools reported that they share faculty with engineering, pre-engineering, or science programs, while only $39 \%$ of the four-year schools share faculty with engineering, science, industrial technology, or pre-engineering programs. Both two- and four-year schools reported sharing all or some laboratories with other programs.

The survey included nine questions regarding the effectiveness of industrial advisory committees in providing various types of support to schools. The four-year school responses in percentages are located in Table 3 and the two-year school percentage responses are located in Table 4.

Table 3. Industrial Advisory Committee Effectiveness - Four-year schools

\begin{tabular}{|l|r|r|r|r|r|}
\hline \multicolumn{1}{|c|}{ Industrial Advisory Committee Provides } & $\begin{array}{c}\text { Very } \\
\text { Effective }\end{array}$ & Effective & Ineffective & $\begin{array}{c}\text { Very } \\
\text { Ineffective }\end{array}$ & $\begin{array}{c}\text { Not } \\
\text { Applicable }\end{array}$ \\
\hline Curriculum guidance & $36 \%$ & $60 \%$ & $2 \%$ & $2 \%$ & $0 \%$ \\
\hline Student scholarships & $2 \%$ & $28 \%$ & $29 \%$ & $9 \%$ & $33 \%$ \\
\hline Co-op employment & $26 \%$ & $47 \%$ & $7 \%$ & $3 \%$ & $17 \%$ \\
\hline Placement for graduates & $29 \%$ & $57 \%$ & $5 \%$ & $3 \%$ & $5 \%$ \\
\hline Recruiting students & $3 \%$ & $45 \%$ & $31 \%$ & $10 \%$ & $10 \%$ \\
\hline Equipment resources & $9 \%$ & $64 \%$ & $17 \%$ & $5 \%$ & $5 \%$ \\
\hline Field trips or training material & $33 \%$ & $50 \%$ & $14 \%$ & $0 \%$ & $3 \%$ \\
\hline Summer employment for faculty & $2 \%$ & $40 \%$ & $26 \%$ & $7 \%$ & $26 \%$ \\
\hline Research/sponsored projects for faculty & $3 \%$ & $17 \%$ & $43 \%$ & $12 \%$ & $24 \%$ \\
\hline
\end{tabular}


Table 4. Industrial Advisory Committee Effectiveness - Two-year schools

\begin{tabular}{|l|r|r|r|r|r|}
\hline \multicolumn{1}{|c|}{ Industrial Advisory Committee Provides } & $\begin{array}{c}\text { Very } \\
\text { Effective }\end{array}$ & Effective & Ineffective & $\begin{array}{c}\text { Very } \\
\text { Ineffective }\end{array}$ & $\begin{array}{c}\text { Not } \\
\text { Applicable }\end{array}$ \\
\hline Curriculum guidance & $17 \%$ & $80 \%$ & $0 \%$ & $0 \%$ & $3 \%$ \\
\hline Student scholarships & $2 \%$ & $12 \%$ & $46 \%$ & $12 \%$ & $28 \%$ \\
\hline Co-op employment & $6 \%$ & $25 \%$ & $17 \%$ & $5 \%$ & $48 \%$ \\
\hline Placement for graduates & $15 \%$ & $34 \%$ & $31 \%$ & $12 \%$ & $8 \%$ \\
\hline Recruiting students & $2 \%$ & $11 \%$ & $38 \%$ & $37 \%$ & $12 \%$ \\
\hline Equipment resources & $6 \%$ & $25 \%$ & $40 \%$ & $3 \%$ & $26 \%$ \\
\hline Field trips or training material & $14 \%$ & $42 \%$ & $26 \%$ & $11 \%$ & $8 \%$ \\
\hline Summer employment for faculty & $0 \%$ & $20 \%$ & $28 \%$ & $12 \%$ & $40 \%$ \\
\hline Research/sponsored projects for faculty & $0 \%$ & $5 \%$ & $25 \%$ & $6 \%$ & $65 \%$ \\
\hline
\end{tabular}

Comparison of the data in Tables 3 and 4 indicate that industrial advisory committees for fouryear schools are slightly more effective in providing resources than their two-year counterparts. Both two- and four-year schools had similar answers to the question about how often industrial advisory committees meet in a year, with half indicating that their committees meet a minimum of once a year and half meet a minimum of twice yearly.

\section{Faculty Characteristics}

This section looks at the number of funded faculty vacancies, faculty attrition, annual faculty salary increase, criteria for promotion, degree requirements of faculty, age of faculty, professional growth budget, part-time faculty usage, and recruitment of part-time faculty.

Fifty-five percent of four-year schools report at least one funded faculty vacancy and a total of $13 \%$ of the schools have two or more vacancies. Sixteen percent of two-year schools reports having one funded vacancy, while a much higher percentage, $42 \%$, have two or more. Both groups indicated that $60 \%$ or more have success in hiring faculty from industry, rather than from other schools/universities or the military.

The percentage of faculty attrition to industry or other institutions within the last four years is $44 \%$ in the four-year schools and $22 \%$ in the two-year schools.

Salary increases for faculty over the last six years has remained constant. At least $75 \%$ of those responding from two- and four-year schools reported that salary increases have remained between $2-4 \%$ since $1994-95$.

Schools were asked to indicate the importance of each criteria normally used in faculty promotion consideration. The average of all responses for two- and four-year schools are in Table 5. Given the discipline's historic emphasis on teaching, it should be no surprise that the dominant criteria for promotion in both groups is teaching. 
Table 5. Promotion Criteria - Four-year and two-year schools

\begin{tabular}{|l|r|r|}
\hline Promotion Criteria & 4-year Ave \% & 2-year Ave \% \\
\hline Teaching & $52 \%$ & $63 \%$ \\
\hline Professional Development & $9 \%$ & $16 \%$ \\
\hline Scholarship & $20 \%$ & $4 \%$ \\
\hline University Service & $10 \%$ & $10 \%$ \\
\hline Community Service & $4 \%$ & $6 \%$ \\
\hline Research & $5 \%$ & $1 \%$ \\
\hline
\end{tabular}

In response to a question concerning the presence of a faculty union/collective bargaining contract, $67 \%$ of the two-year schools and only $23 \%$ of the four-year schools responded affirmatively.

Seventy-four percent of four-year schools reported that the minimum degree required for hiring a full-time engineering technology faculty member is a Masters, while 26\% indicated that a Ph.D. is required. At two-year schools, 55\% require a Masters degree, 35\% require a Bachelor Degree, and $10 \%$ require an Associate Degree. When asked if the highest degree needed to be in the particular field in which the instructor is teaching, the answers were about the same for two- and four-year schools; approximately 50\% responded yes and 50\% responded no.

The average age of the faculty in both two- and four-year schools is 40 to 54 years old. Table 6 shows the age range percentages listed by group.

Table 6. Faculty Ages - Four-year and two-year schools

\begin{tabular}{|c|r|r|}
\hline & 4-year & 2-year \\
\hline Age Range & Avg $\%$ & Avg $\%$ \\
\hline $25-39$ & $4 \%$ & $2 \%$ \\
\hline $40-49$ & $42 \%$ & $52 \%$ \\
\hline $50-54$ & $50 \%$ & $33 \%$ \\
\hline $55-59$ & $4 \%$ & $3 \%$ \\
\hline $60+$ & $0 \%$ & $10 \%$ \\
\hline
\end{tabular}

A majority of both groups indicated that they have a budget allocation for the professional growth of faculty. Eighty-six percent of the two-year schools and $96 \%$ of the four-year schools responded affirmatively to the question.

Part-time (Associate) faculty are used by both two- and four- year schools as shown in Table 7.

Table 7. Part-time Faculty Use - Four-year and two-year schools

\begin{tabular}{|c|r|r|}
\hline & 4-year & 2-year \\
\hline \% PT Faculty & Avg \% & Avg \% \\
\hline Less than $20 \%$ & $68 \%$ & $54 \%$ \\
\hline $20-40 \%$ & $17 \%$ & $24 \%$ \\
\hline $41-60 \%$ & $9 \%$ & $9 \%$ \\
\hline $61-80 \%$ & $4 \%$ & $3 \%$ \\
\hline More than $80 \%$ & $2 \%$ & $10 \%$ \\
\hline
\end{tabular}


Two-year schools indicated that they had a harder time recruiting part-time or adjunct faculty than did four-year schools. This may be attributed to the lower pay for part-time faculty at twoyear institutions. Sixty percent of two-year schools pay anywhere from $\$ 450$ to $\$ 600$ per credit/contact hour and 30\% offer less than $\$ 400$ per credit/contact hour. Four-year schools reported higher pay. Thirty percent pay $\$ 450$ to $\$ 600,43 \%$ pay $\$ 650$ to $\$ 800$, and $11 \%$ pay greater than $\$ 850$ per credit/contact hour for part-time faculty.

Student Characteristics

This section reports on student characteristics, such as the percentage of minority, female and physically disadvantaged students, as well as the average age of student populations.

Questions in this section differ slightly for two-and four-year schools. Eighty percent of the fouryear schools surveyed indicated that the average age of students in their programs is between 21 and 26 years old. The oldest students were younger than 50. A majority of the four-year schools reported that five to ten percent of their student population is female. The percentage of minority students in four-year schools varied, as shown in Table 8.

Table 8. Minority Students - Four-year schools

\begin{tabular}{|c|r|r|r|}
\hline & Minority & Female & \multicolumn{1}{c|}{ Physically } \\
\hline & Students & Students & Disadvantaged \\
\hline 4-year Schools & Avg $\%$ & Avg $\%$ & \multicolumn{1}{c|}{ Avg $\%$} \\
\hline Less than $5 \%$ & $29 \%$ & $10 \%$ & $96 \%$ \\
\hline $5-10 \%$ & $27 \%$ & $53 \%$ & $0 \%$ \\
\hline $11-20 \%$ & $13 \%$ & $31 \%$ & $2 \%$ \\
\hline $21-50 \%$ & $27 \%$ & $6 \%$ & $2 \%$ \\
\hline More than $50 \%$ & $4 \%$ & $0 \%$ & $0 \%$ \\
\hline
\end{tabular}

Seventy- nine percent of two-year schools reported that the average age of students in their programs was between 20 and 30 years old with the oldest student being less than 35 years old. Sixty-six percent of the two-year schools, replied that females comprised $10 \%$ or less of their student population. The percentage of minority students in two-year schools also varied, as shown in Table 9.

Table 9. Minority Students - Two-year schools

\begin{tabular}{|c|r|r|r|}
\hline & Minority & Female & \multicolumn{1}{c|}{ Physically } \\
\hline & Students & Students & Disadvantaged \\
\hline 2-year Schools & Avg $\%$ & Avg $\%$ & \multicolumn{1}{c|}{ Avg \% } \\
\hline Less than $5 \%$ & $20 \%$ & $27 \%$ & $69 \%$ \\
\hline $5-10 \%$ & $15 \%$ & $39 \%$ & $26 \%$ \\
\hline $11-20 \%$ & $32 \%$ & $26 \%$ & $3 \%$ \\
\hline $21-50 \%$ & $30 \%$ & $8 \%$ & $0 \%$ \\
\hline More than 50\% & $3 \%$ & $0 \%$ & $2 \%$ \\
\hline
\end{tabular}


Enrollment, Recruiting, Retention, Placement, and Follow-up

This section looks at the results of questions on enrollment history, enrollment projections, percentage of completion of degrees, placement and starting salaries of graduates, alumni activities, fall enrollment by program, and graduation rates by program.

The four-year schools characterized their enrollment history from 1994-98. Twenty-seven percent indicated a stable enrollment, $27 \%$ experienced growth, and $46 \%$ experienced a decline. Schools in which enrollment rates grew, experienced a 35\% increase. Schools with a decrease in enrollment showed an average of $11 \%$ decline. Responding to questions about enrollment projections for 1999-00, 50\% of the four-year schools surveyed stability in enrollment, 44\% expected growth, and only $6 \%$ projected a decline. The schools expecting an increase looked forward to a $13 \%$ increase, while those forecasting a decline expected an $11 \%$ attrition.

Thirty-one percent of the two-year schools characterized their enrollment history from 1994-98 as stable while, $22 \%$ experienced growth and $47 \%$ experienced a decline. For schools indicating growth, the average percent of growth during this four-year period was $16 \%$. Schools showing a decrease in enrollment showed a $23 \%$ decline for the same period. When asked about enrollment projections for the period $1999-2000,45 \%$ replied that they expected stability in enrollment, $27 \%$ expected growth, and $29 \%$ were looking at a decline. The average amount expected for those looking towards a growth period was $10 \%$, while the average for expected decline was $19 \%$.

Four-year schools were asked what percentage of each entering freshman class completes the engineering technology Bachelor of Science within five years. Similarly, two-year schools were asked what percentage of the freshman class completes the Associate Degree within three years. The results are tabulated in Table 10. As can be seen, the record of degree completion within the time frame for the Associate Degree is much better than for Bachelor's Degree.

Table 10. Freshman Degree Completion - Four-year and two-year schools

\begin{tabular}{|c|c|c|}
\hline Completion of & 4-year & 2-year \\
\hline Degree & Avg \% & Avg \% \\
\hline Less than $20 \%$ & $7 \%$ & $26 \%$ \\
\hline $20-40 \%$ & $37 \%$ & $39 \%$ \\
\hline $41-60 \%$ & $21 \%$ & $26 \%$ \\
\hline $61-80 \%$ & $23 \%$ & $4 \%$ \\
\hline More than $80 \%$ & $12 \%$ & $5 \%$ \\
\hline
\end{tabular}

When asked if there was a retention program for all students, $72 \%$ of the four-year schools and $67 \%$ of the two-year schools responded in the affirmative.

All the schools surveyed were asked to respond to a question concerning placement of their graduates in discipline-related positions soon after graduation. Table 11 shows the differences as reported by two- and four-years schools. The four-year schools overwhelmingly indicated that more than $80 \%$ of their graduates are employed in discipline-related positions shortly after graduation. 
Table 11. Placement of Graduates - Four-year and two-year schools

\begin{tabular}{|c|c|c|}
\hline Placement of & 4-year & 2-year \\
\hline Graduates & Avg \% & Avg \% \\
\hline Less than $20 \%$ & $14 \%$ & $30 \%$ \\
\hline $20-40 \%$ & $5 \%$ & $2 \%$ \\
\hline $41-60 \%$ & $0 \%$ & $25 \%$ \\
\hline $61-80 \%$ & $0 \%$ & $9 \%$ \\
\hline More than $80 \%$ & $81 \%$ & $34 \%$ \\
\hline
\end{tabular}

Average starting salaries for graduates are shown in Table 12. As expected, starting salaries for graduates with a Baccalaureate Degree are higher than Associate Degree graduates.

Table 12. Starting Salaries of Graduates - Four-year and two-year schools

\begin{tabular}{|c|c|c|c|}
\hline & 4-year & & 2-year \\
\hline Starting Salary & Avg \% & Starting Salary & Avg \% \\
\hline under $\$ 30,000$ & $2 \%$ & under $\$ 20,000$ & $2 \%$ \\
\hline$\$ 31,000-\$ 35,000$ & $16 \%$ & $\$ 21,000-\$ 25,000$ & $20 \%$ \\
\hline$\$ 36,000-\$ 40,000$ & $49 \%$ & $\$ 26,000-\$ 30,000$ & $71 \%$ \\
\hline$\$ 41,000-\$ 45,000$ & $24 \%$ & $\$ 31,000-\$ 35,000$ & $5 \%$ \\
\hline$\$ 46,000$ and over & $9 \%$ & $\$ 36,000$ and over & $2 \%$ \\
\hline
\end{tabular}

Forty-six percent of four-year school alumni actively participate in ongoing departmental activities, while only $15 \%$ of two-year schools graduates participate. When asked if alumni contribute to an alumni fund, $58 \%$ of the four-year and only $2 \%$ of the two-year schools answered yes.

Both two- and four-year institutions were asked to list degree programs along with enrollment and graduation data. Degrees were grouped into the five categories shown in Table 13. Among the schools that replied, enrollments in the electrical and mechanical/manufacturing programs were the highest for four-year schools, while enrollments in the civil/construction and electrical degrees were the largest in the two-year programs.

Table 13. Enrollment by Program - Four-year and two-year schools

\begin{tabular}{|l|r|r|r|}
\hline ENROLLMENT - FALL 1998 & 4-year & 2-year & \multicolumn{1}{|c|}{ Total } \\
\hline Computer & 1,290 & 634 & 1,924 \\
\hline Civil \& Construction & 2,110 & 1,725 & 3,835 \\
\hline Electrical & 5,127 & 3,850 & 8,977 \\
\hline Mechanical \& Manufacturing & 4,748 & 562 & 5,310 \\
\hline Other & 2,892 & 1,504 & 4,396 \\
\hline TOTAL & 16,167 & 8,275 & 24,442 \\
\hline
\end{tabular}

The number of graduates for two- and four-year schools are listed in Table 14. Because of the larger number of students enrolled in electrical programs, it should be no surprise that the numbers are higher in this category. 
Table 14. Graduates by Program - Four-year and two-year schools

\begin{tabular}{|l|r|r|r|}
\hline GRADUATION - 1998-99 & \multicolumn{1}{|c|}{ 4-year } & 2-year & \multicolumn{1}{|c|}{ Total } \\
\hline Computer & 110 & 227 & 337 \\
\hline Civil \& Construction & 109 & 142 & 251 \\
\hline Electrical & 454 & 654 & 1,108 \\
\hline Mechanical \& Manufacturing & 405 & 54 & 459 \\
\hline Other & 461 & 290 & 751 \\
\hline TOTAL & 1,539 & 1,367 & 2,906 \\
\hline
\end{tabular}

\section{Summary}

The results presented in this paper are taken from the data received from the two- and four- year schools participating in the Engineering Technology Trends and Development Survey as of November 1999. The 1999 Engineering Technology Trends and Developments Survey Report is scheduled to be completed and published by the end of spring 2000. The final report may vary slightly from the results presented in this paper because data from late participants are not included. In addition, this paper addresses only some of the questions that were asked of engineering technology schools. The final survey report will be distributed to participants and will be reported at the ASEE 2000 conference in St. Louis. This report will include the results from approximately 130 questions concerning administrative features, programs, faculty, student characteristics, enrollment, recruitment, retention, and follow-up for two- and four-year engineering technology programs. Data from previous surveys for four-year programs will be included in the report to allow for comparison of recent developments and trends. The 1999 survey will be the base line for development and trends of two-year engineering technology programs, given that this is the first year for two-year programs to be surveyed.

The authors want to acknowledge the support and assistance of Ashok Agrawal, Russell Aubrey, William Beston, Walter Buchanan, Frank Gourley, David Hata, Warren Hill, Surinder Jain, Ronald Land, Robert Mott, Kevin Taylor, Edward Tezak, George Timblin, and Robert Speck in assisting with the development of the survey questions. The authors also want to thank Carmen Buchanan and Jeremy York for assisting in the collection of the survey data. Last but not least, the authors are eternally grateful for the technical knowledge and work of Mary Reiman who developed the survey database.

Bibliography

1. Fox, P.L., "1999 National Developments and Trends in Engineering Technology Education Report." Purdue School of Engineering and Technology, IUPUI.

\section{PATRICIA L. FOX}

Patricia L. Fox is the Assistant Dean for Administration and Finance and an Assistant Professor of Organizational Leadership and Supervision in the Purdue School of Engineering and Technology at Indiana University-Purdue University Indianapolis (IUPUI). Pat is the chief financial officer of the school and has been author and co-author of the national Engineering Technology Faculty Salary Survey since 1980. In addition to her administrative duties, Pat teaches human relations in organizations in the Department of Organizational Leadership and Supervision. She holds a MBA from Butler University. 


\section{STEPHEN P. HUNDLEY}

Stephen P. Hundley is an Assistant Professor of Organizational Leadership and Supervision in the Purdue School of Engineering and Technology at Indiana University-Purdue University Indianapolis (IUPUI), where he teaches human resources management, labor relations, and strategic compensation. Prior to his appointment at IUPUI, Stephen worked in training, human resources, and management consulting. He regularly speaks on higher education and human resources issues to a variety of audiences, and he is the author of two forthcoming books: Internal Consulting in Higher Education Human Resource Management (College and University Personnel Association, 2000) and A Leader's Guide to Understanding Organizations (Sage Publications, 2001). Finally, he holds a Ph.D. from American University, and is certified by the Society for Human Resource Management as a Senior Professional in Human Resources. 